\title{
Assessing virtual and on-site technical trainings during the first year of covid-19 pandemic
}

\author{
Vyta W. Hanifah*, Didu Wahyudi, Tika Tresnawati, Amalia Ulpah, Catur O. I. Hastuti, \\ Rahmawati, Nurhayati, and Agus Muharam \\ Indonesian Center for Agricultural Technology Assessment and Development, J1 Tentara Pelajar 10 \\ Kota Bogor, Jawa Barat, Indonesia
}

\begin{abstract}
In 2020, Covid-19 pandemic firstly hit many countries including Indonesia. Since then, the methods on disseminating the agricultural technology have evolved accordingly. This paper assessed nine series of virtual and on-site technical trainings (or the so-called Bimtek in this paper) carried out from February to November 2020 in nine sub-districts from five provinces. Zoom application was used to deliver the materials during virtual Bimtek. Whilst, on-site training applied such methods: meeting in the classroom and field visit to practice the technology. The participants were diverse, among others: farmers and millennial farmers, extension officers, lecturers, college students and community (551 in total). The nature of participants depended on the type of Bimtek. Results showed that both Bimtek had the range of value between $70-85 \%$ in term of materials to meet the needs, materials to be applied, motivation and technical assistance from resource person. However, the percentage of knowledge change in virtual was higher than that in on-site Bimtek. Initial assessment showed that participants had good knowledge in remembering the technology, even some had also applied the technology in their farming practice. Thus, both Bimtek could improve farmers' knowledge, from which the intention to change the farming practice could be persuaded.
\end{abstract}

\section{Introduction}

Covid-19 pandemic that began striking in 2020 has impacted severely the lives of many countries around the world, including Indonesia. The Indonesian government declared the coronavirus outbreak in the country as a national disaster. Currently, many countries are struggling to contain the spread of new variants of the virus. On the other hand, during the Covid-19 pandemic, the agricultural sector proved to be the highest contributor to national economic growth. The contribution of the agricultural sector to Gross Domestic Product (GDP) in the second quarter of 2020 increased from the second quarter of 2019 (from $13.57 \%$ to $15.46 \%$ ) [1]. Similar data was also presented by National Development Planning Agency [2] in Indonesia and The World Economic Development Report which stated that the agricultural sector contributed to the growth of non-oil and gas exports by $16.0 \%$ (Year on Year/YoY).

* Corresponding author: vytahanifah@gmail.com 
This shows that the performance of the agricultural actors is still able to ensure national food stability in the midst of the global economic slowdown due to the pandemic. National Development Planning Agency (2020) [2] also stated that the impact of the slowdown in agricultural commodities was not as large as other commodities. This is an evidence of the agricultural sector resilience in supporting the national economy. The Ministry of Agriculture's programs, especially in 2021 to accelerate economic recovery and social reforms include: Availability, Access and Consumption of Quality Food Program; Agricultural Research and Innovation Strengthening Program; Industrial Value Added and Competitiveness Program; Vocational Education and Training Programs; and Management Support Program [3].

Among these programs, Indonesian Agency for Agricultural Research and Development (IAARD) received the mandate to support the main activities of the program in strengthening agricultural research and innovation. The form of support is, among others, accelerating the use of agricultural innovation technology through strengthening research capacity in the regions, research/breeding/purification of superior plant varieties and livestock lines, and down-streaming innovation [3]. The targets of the program include: increasing agricultural production and productivity by $7 \%$, suppressing yield loss from $12 \%$ to $5 \%$, and production cost efficiency through the development of agricultural areas based on farmer corporations. For this reason, one of the supports from IAARD that considered having a massive impact is the down-streaming of agricultural innovation, one of which is by facilitating series of technical trainings.

Agricultural innovation is a product of the process: (1) research that produces inventions or technologies, (2) technology assessment for site-specific conditions and user needs, and (3) dissemination of technology to users, which is included in the innovation system as described in MoA Regulation Number 03/ 2005. The research products are in the form of new superior varieties, technology, and models or prototypes [4]. In the context of agricultural development, dissemination is practically defined as a method and process of delivering technological innovations to be adopted by users as stated in the Agriculture Ministry Regulation number 20/2008. IAARD has produced various technological innovations and has disseminated one of them in the form of providing technical guidance. The dissemination approach through technical guidance is an effort to accelerate the transfer of technology from the source of innovation to the user. In technical guidance, participants are given technical training that is useful for increasing knowledge, skills, and even competence.

Technical training is also one of the extension methods that is considered effective to deliver technically nuanced material because it is equipped with practices leading to improve farmers' livelihood. Accordingly, the study on the effects of trainings in soil and water conservation in farming practice for farmers in Ethiopia highlands indicated that the participants gained higher average income from agriculture because of the improved farmers' abilities to generate income from crops [5]. During the Covid-19 pandemic, the extension approach, including technical training, was also adjusted due to restrictions on mass gatherings. Extension and advisory services play an indispensable role at the frontline of the response to the pandemic in rural areas [6].

Therefore, it is necessary to adapt the extension approach in the form of virtual implementation. However, the offline guidance and technology approach through implementation at selected locations can still be implemented by applying strictly health protocol standards to prevent the transmission and spread of the virus. This paper aimed to assess nine series of virtual and on-site technical trainings (or the so-called Bimtek in this paper) during the first year of the Covid-19 pandemic. 


\section{Methodology}

\subsection{Time and location}

Series of virtual and on-site Bimtek were carried out in nine regencies of five provinces in Indonesia from February to November 2020. The virtual one was conducted in three out of nine regencies, namely: Serang-Banten Provinsi, Banjarmasin-South Kalimantan Provinsi, and Makasar-South Sulawesi Provinsi. The other six regencies as a location for on-site Bimtek included three from South Sulawesi Province (Takalar, Bantaeng, and Gowa District), two from West Java Province (Bogor and Cianjur District), and one from Central Sulawesi Province (Poso District).

Zoom application was used to deliver the materials during virtual Bimtek due to the movement restriction during the pandemic where most people worked from home. Material of presentation was distributed via a Google Drive as well as a way to collect participant's information regarding their contacts for future communication, such as: for survey on initial assessment by email.

Whilst, on-site Bimtek applied such methods as: meeting in the classroom and field visit to practice the technology delivered by the resource person. The classroom for on-site Bimtek was in a meeting room that belongs to research institute or assessment institute or local community. The supported facility in-house training was prepared by local organisers (Assessment Institute for Agricultural Technology/AIAT in each province), such as screen, projector, sound system, etc. We strongly applied the Covid-19 health protocol procedure during on-site Bimtek to avoid the virus contamination and infection among people in the same room, such as physical distancing, wearing face mask, and using hand-sanitizer.

\subsection{Participants and topics covered}

The participants in both trainings were diverse, among others: farmers and millennial farmers, extension officers, lecturers, college students and community (551 in total). However, the nature of virtual Bimtek was more various than that in on-site Bimtek. In virtual one, participants could access the link which might be shared by registered people; hence, the coverage of people involvement broadened. The number of participants in this type of training reached more than 100 people in each site.

Meanwhile, the organiser of on-site Bimtek released a letter of invitation to the local office of Agriculture Service to invite the targeted participants to attend in person to the venue. Targeted participants referred to farmers or millennial farmers and extension workers who were managing or working on either horticulture, estate crops, or livestock farms. The number of participants that attended the on-site training was around 25-50 people, depending on the capacity of meeting room to be able to accommodate the health protocol implementation.

We considered different criteria when inviting the participants to the Bimtek. The criteria for invitees of the virtual Bimtek included: (i) having own device either mobile phone or computer; (ii) actively supervising farmers; (iii) high motivation to work with farmers to develop local agriculture; and (iv) good interpersonal relationship with farmers in order to ease the process of technology transfer to others. While the criteria for invitees of on-site Bimtek, among others, were: (i) actively managing high value commodities; (ii) engaged actively in farmer group or federated farmer group; and likewise in virtual, good interpersonal relationship with extension workers and farmers in order to ease the process of technology transfer from farmer to farmers (F2F).

Topics covered during trainings related to the theme on the commodities of horticulture, estate crops, or livestock. Delivered topics differed among the sites and this was determined 
by the potency of specific location in each site. List of the topics in each site is displayed in Table 1.

Table 1. Topics covered during technical training in 9 sites.

\begin{tabular}{|l|l|}
\hline \multicolumn{1}{|c|}{ Sites (Districts) } & \multicolumn{1}{c|}{ Topic } \\
\hline Serang (virtual) & $\begin{array}{l}\text { Chili cultivation; Breeding of native chicken "KUB"; and Feed } \\
\text { technology utilising biomass of agriculture by-product }\end{array}$ \\
\hline Banjarmasin (virtual) & $\begin{array}{l}\text { Citrus cultivation; Post-harvest on medicinal plants; and Local } \\
\text { feed resources for additive nutrition for chicken and duck }\end{array}$ \\
\hline Makasar (virtual) & $\begin{array}{l}\text { Chili cultivation; Breeding of native chicken "KUB"; and Cocoa } \\
\text { cultivation }\end{array}$ \\
\hline Bantaeng (on-site) & Processing chili; and Coffee cultivation \\
\hline Takalar (on-site) & $\begin{array}{l}\text { Processing chili; Breeding of native chicken "KUB"; and Feed } \\
\text { technology utilising biomass of agriculture by-product }\end{array}$ \\
\hline Gowa (on-site) & $\begin{array}{l}\text { Hydroponic; and Fruit cultivation (grapes, longan, and dragon } \\
\text { fruit) }\end{array}$ \\
\hline Bogor (on-site) & Chili cultivation; and Processing chili \\
\hline Cianjur (on-site) & Chili cultivation; and Processing chili \\
\hline Poso (on-site) & Coffee cultivation; and Economic added value for coffee \\
\hline
\end{tabular}

\subsection{Data collection and analysis}

Before topic presentation, participants in both trainings were required to answer set of pretest questionnaires. Likewise, after the session ended, before closing, participants answered set of post-test questionnaires and also set of process evaluation form.

In virtual Bimtek, pre- and post-test was done using game-based learning application the so-called Kahoot Games. This app is a technology platform combining between experience and evaluation through interactive game as it is equipped with monitoring system on participant's response [7]. Furthermore, [8] notifies that Kahoot could bring the attractiveness during learning process to be interactive, conducive, and easy to monitor the learning result. In on-site Bimtek, pre- and post-test as well as process evaluation used the printed version of questionnaire. The question was set to be the same between pre- and post-test, consisting of several questions regarding the level of knowledge about each topic in each site. The rank of knowledge comprised five scores, which were: $1=$ no knowledge; $2=$ poor knowledge; $3=$ less knowledge; 4=good knowledge; $5=$ excellent knowledge. From pre- and post-test, we could evaluate the knowledge change that also indicate the effectiveness of trainings.

The process evaluation in virtual training used a separated form which was distributed via a link of Google Form. While in on-site training used the printed version. The question of process evaluation included such aspects: input (presentation, facilities, resource person); process (the way of delivering the topics, discussion session, and practice in the field); output (the result of pre and post-test questionnaire); and benefit (improved knowledge on delivered technology). Participant then decided the rating among five level of evaluation score, which were: $1=$ not appropriate; $2=$ less appropriate; $3=$ neutral; $4=$ likely appropriate; $5=$ much appropriate.

Data from pre-, post-test and evaluation were analysed using descriptive analysis in Microsoft Excel. The answers were displayed in percentage of frequency distribution and in graphic presentation. 


\section{Results and discussion}

\subsection{Advantages and disadvantages of each training}

In general, both type of trainings had the same purpose, which was to improve participant's knowledge and skill on technology application. However, the different nature of virtual and on-site training must have advantages and disadvantages. Table 2 describes those from each training based on some aspects.

Table 2. Features of virtual and on-site Bimtek.

\begin{tabular}{|l|l|l|}
\hline \multicolumn{1}{|c|}{ Aspect } & \multicolumn{1}{c|}{ Virtual Bimtek } & \multicolumn{1}{c|}{ On-site Bimtek } \\
\hline Participant coverage & Wider number, various & Smaller number, limited target \\
\hline Facility & $\begin{array}{l}\text { Data internet, wi-fi connection, } \\
\text { devices (mobile/computer) }\end{array}$ & $\begin{array}{l}\text { Meeting room, field visit for } \\
\text { practice }\end{array}$ \\
\hline Material presentation & $\begin{array}{l}\text { Visually limited, time constraint } \\
\text { for interactive discussion }\end{array}$ & $\begin{array}{l}\text { In-depth learning, interactive } \\
\text { discussion, learning by doing in } \\
\text { field visit }\end{array}$ \\
\hline $\begin{array}{l}\text { Risk of virus } \\
\text { contamination }\end{array}$ & $\begin{array}{l}\text { None (each was joining } \\
\text { virtually from home) }\end{array}$ & High risk, susceptible to infection \\
\hline
\end{tabular}

In regards to the coverage, virtual training could engage more participants in term of wider number and various characteristics because there was no limitation in certain areas. It means that participants could be from different province, even possibly different country. Besides, scheduled time for the virtual was also manageable as the organiser did not need to coordinate about the venue, logistics and transportation. Meanwhile, on-site training had smaller number and limited target of participants because the organiser had to apply the health protocol to avoid Covid-19 contamination. Therefore, the number really depended on the size of meeting room.

Internet connection is a pivotal key to running virtual training, for both organiser and participants. Besides, they also needed to understand the know-how of operating the online application for meeting (such as Zoom meeting). Compared to the on-site training, the participants did not need to have internet connection, they just needed to attend to the venue without prior preparation. In addition, the organiser of on-site training had to prepare the facility, the logistics, and the transportation, meaning that they were busier in preparation, during the implementation, and after the closing.

Material presentation during virtual training was visually limited based on PowerPoint shared screen from the resource person or the organiser. Even though the presentation could be in the form of video presentation, it still seemed to be less attractive. There was also time constraint in the virtual training to have such an interactive discussion. Conversely, the onsite training provided more time for participants to have in-depth discussion with the resource person. Differently, they also learnt directly to practice the technology during field visit. This point was not applied in the virtual training.

During Covid-19 pandemic, it seemed that virtual training was safer owing to none chance of virus contamination among involved people. Differently, on-site training seemed to still cause a high risk of virus contamination because there was possible physical contact among people even though the organiser had encouraged strictly to apply the health protocol. 


\subsection{Comparison between virtual and on-site technical training}

First comparison deals with the characteristics of participants based on gender in each Bimtek (Table 3). This data was gathered at the same time when we conducted pre- and post-test. It can be seen that there was different gender dominated in each training that the participation of women was inversely related to that of men in both Bimtek. The virtual Bimtek had more male attendees (56\%), whilst the on-site Bimtek had more female attendees (53\%).

Table 3. Participants' characteristics comparison between virtual and on-site Bimtek.

\begin{tabular}{|l|c|c|c|c|}
\hline \multirow{2}{*}{ Characteristics } & \multicolumn{2}{c|}{ Virtual } & \multicolumn{2}{c|}{ On-site } \\
\cline { 2 - 5 } & Male & Female & Male & Female \\
\hline Percentage of participants (\%) & 56.52 & 43.48 & 46.8 & 53.2 \\
\hline Average age (year) & 43 & 38 & 41 & 37 \\
\hline The youngest age (year) & 25 & 26 & 26 & 26 \\
\hline The oldest age (year) & 57 & 51 & 58 & 61 \\
\hline Average work experience (year) & 24 & 15 & 22 & 12 \\
\hline The least experience in farming (year) & 0 & 0 & 0 & 0 \\
\hline The longest experience in farming (year) & 35 & 33 & 33 & 37 \\
\hline
\end{tabular}

Gender, age, and work experience were identified as participant characteristics that influenced participant's responses. In this case, the physical appearance of the participants will be reflected in their level of knowledge and appreciation for technical training activities, which resulted in gaining an understanding of the character. According to Table 1, the participants ranged in the average age from 37 to 43 years old, with the youngest one was 25 years old and the oldest was 61 years old. In terms of work experience, the average participant had 12-24 years of experience. The least experience was stated by the youngest participants, while the longest experience stated by the oldest made up in the range from 33-37 year long.

Next comparison conveyed participants perception on five aspects (Fig. 1), including: (i) gaining new knowledge from Bimtek, (ii) topic meets the needs; (iii) applicable technology; (iv) encouragement from resource person; and (v) optimism to practice in the field. The quality of participant responses towards virtual and on-site technical training activities was assessed by measuring those five aspects in the score range of 1-5 (see Method section, about evaluation form). Overall, the participants in both Bimtek ranked a score of 3-5, indicating that the aspects accepted by the participants were satisfactory. However, there were four assessment aspects for which the participants ranked a score range of 1-2, indicating that they were still unsure about implementing the aspect.

Figure 1, shows that the greatest perception (performed by score 4) in three aspects (Fig. 1.a, 1.b, and 1.c) from on-site training was higher than that from virtual. In other words, most of the attendees of on-site training assumed that: (i) they gained new knowledge from the training; (ii) they supposed the delivered topics meet their needs; and (iii) they thought the technology was applicable in their farming practice. It can be explained, by referring the list of topics (Table 1) and the method in section 2, that the topics delivered in on-site Bimtek was followed by the practical exercise either by visiting the field or in-house practice. 


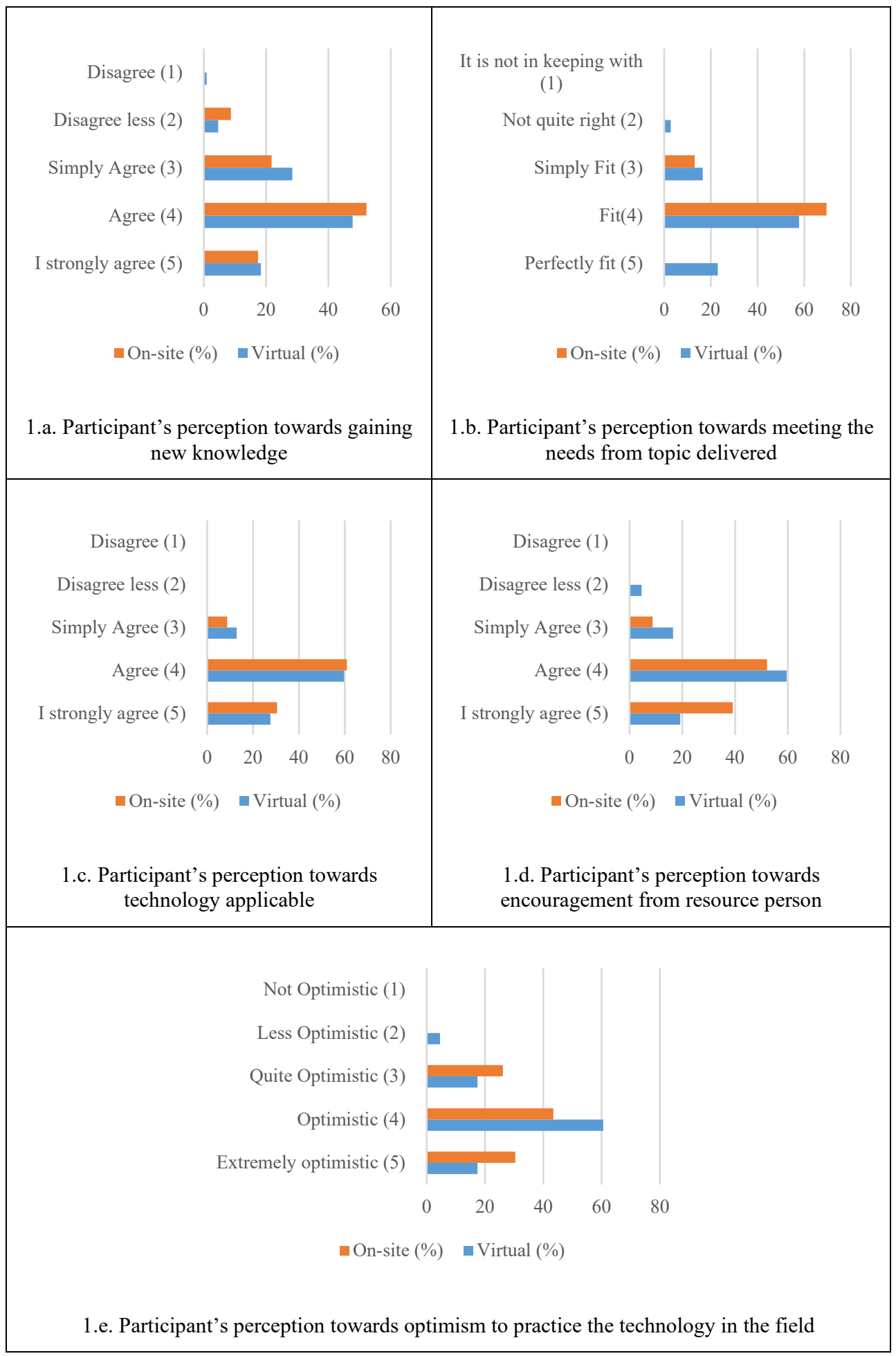

Fig. 1. Percentage of participant's perception towards five aspects for each Bimtek. 
However, Figure 1.c showed a tiny discrepancy of perception between participants of onsite and virtual Bimtek. All argued that the technology demonstrated in the material of presentation was applicable at the farming practice. On the contrary, the other two aspects (1.d and 1.e) showed that the greatest perception (performed by score 4) in virtual training was higher than that in on-site training. It explained that despite the disadvantages the virtual training had, the participants assumed that they were encouraged by the performance of resource person, so then leading to their optimism to practice the technology in the field. A study on training motivation by [9] supports this assumption, mentioning that self-efficacy influences the personality on how people is speaking during the training, that then improve motivation of the participants, as also stated by [10].

\subsection{Knowledge change}

Knowledge change is illustrated from the difference score in pre-test and post-test both in virtual and on-site Bimtek. Unfortunately, we applied a different method to evaluate the alteration, which were, testing with Kahoot using the same set of theoretical multiple-choice questions in virtual Bimtek and testing with printed questionnaires using Likert scale of file levels in on-site Bimtek. Overall, the percentage of knowledge change in virtual Bimtek was higher than that in on-site Bimtek. This can be argued that the participants in virtual were more various in term of their occupations and educations, whilst in on-site Bimtek all were targeted farmers.

In virtual Bimtek, the purpose of the test was to observe the participants' knowledge change by the end of the Bimtek session. Each participants received an anonymous ID to grant individual access to Kahoot within the classic game mode ("Player vs Player 1:1 Devices"). The test questions and answer choices were presented in a randomized manner. The participants had 20 seconds to pick an answer before Kahoot automatically moved on to the next question. The results from the tests are shown in Figure 2. The Figure showed the percentage of correct answers for each site. In the case of overall results, the virtual Bimtek participants changed from the average of total score 5,699.19 to $10,809.05$, thus gaining knowledge change of $89.66 \%$. Kahoot statistical data also presented an overview of participants' knowledge change in the virtual Bimtek. It was noted that the highest score of participants was 14,170 in the pre-test and 16,914 in the post-test. The average time spent on each question also decreased from $6.146 \mathrm{~s}$ to $4.607 \mathrm{~s}$. The decrease on average time spent for each question implied participants' acceptance to the lecture sessions of virtual Bimtek.

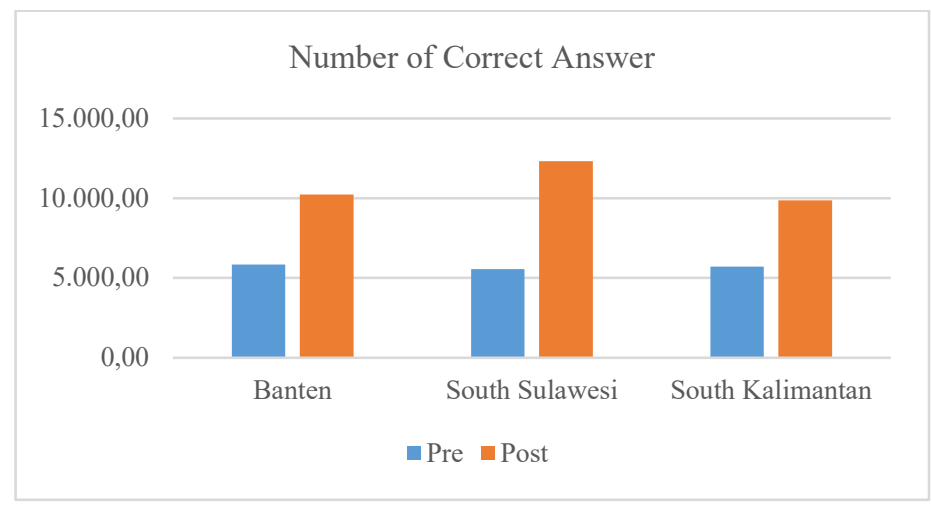

Fig. 2. Comparison of the test results before and after virtual Bimtek session.

The method used in on-site Bimtek included class presentation, discussion as well as practical exercise in the field. The questions in pre- and post-test covered those three 
methods. Table 4 showed that there was an increase in knowledge between before and after on-site training, which accounted for 0.74 point on average. The range of average score before training was between score 1 and score 2, whilst after training it ranged between score 3 and score 4. It means that before attending the on-site Bimtek, participants had either no or poor knowledge (score 1 - score 2, individually) on the topics. However, after the on-site Bimtek, they performed an increase knowledge at the level of having less or excellent knowledge (score 3 - score 5, individually).

Several previous studies argued that technical training or Bimtek is able to improve participant's knowledge, as found in research by [11 - 13]. Training and advisory services are the methods to raise awareness and persuade the targets in order to adopt the new practice of technology [14 - 15].

Table 4. Knowledge change based on the score from pre- and post-test in on-site Bimtek.

\begin{tabular}{|l|r|r|}
\hline \multicolumn{1}{|c|}{ Scores } & \multicolumn{2}{|c|}{ On-site Bimtek } \\
\hline & Pre-test & \multicolumn{1}{c|}{ Post-test } \\
\hline Average of score & $2.37 \pm 0.87$ & $3.11 \pm 0.66$ \\
\hline Average of minimal score & 1.17 & 1.20 \\
\hline Average of maximal score & 4.70 & 4.70 \\
\hline
\end{tabular}

Another presentation to show the change between before and after on-site Bimtek can be seen in Table 5. This table counted the distributed frequency of the participants based on Likert score. After Bimtek, there was a decrease in the number of participants at the score 1 (having no knowledge) and score 2 (having poor knowledge); conversely, there was an increase at the score 3 (having less knowledge), score 4 (having good knowledge) and score 5 (having excellent knowledge). These increases corresponded with the Fig. 1.b. that the delivered topics meet farmers' needs. In addition, the competency from resource person also played an essential role to bring the understanding among various background of participants, as stated by [16 - 17] that the competency contributes the most towards the successful learning/training.

Table 5. Change in number of participants based on the score from pre- and post-test in on-site Bimtek.

\begin{tabular}{|l|c|c|}
\hline \multirow{2}{*}{ Likert score } & \multicolumn{2}{|c|}{ Percentage of participants (\%) } \\
\cline { 2 - 3 } & Pre-test & Post-test \\
\hline Score 1 & 14.95 & 4.48 \\
\hline Score 2 & 30.46 & 21.21 \\
\hline Score 3 & 28.63 & 34.26 \\
\hline Score 4 & 16.86 & 26.48 \\
\hline Score 5 & 5.10 & 13.57 \\
\hline
\end{tabular}

\subsection{Initial assessment}

An initial assessment on the effect of training for all participants in both Bimtek was carried out using Google Form. Effect of training could be used to better understand the ways in which the methods of training influence the participants [5]. Owing to the limited time to conduct the assessment towards the farming practice, the assessment was only purposed towards the knowledge of participants and intention to apply the technology. Like the preand post-test, five levels of Likert score were applied, which were: (1) poorest knowledge, 
can't remember anything, no application; (2) fair knowledge, fair understanding, applied 1 technology discontinuously; (3) less knowledge, less understanding, applied 2 technologies discontinuously; (4) good knowledge, good understanding, applied 1-2 technologies continuously; and (5) excellent knowledge, excellent understanding, applied more than 3 technologies continuously.

Table 6 showed that the participants had less-to-good knowledge and understanding, even though some had also applied in their farming practice, yet discontinuously. This number implied the positive achievement from both Bimtek considering the time lag between the topics delivery and the assessment that was carried out at the end of last year. The intention to practice the technology was assumed occurring because the technology could answer the farming problems in the field. Study [18] on assessing the impact of training for farmers in Uganda found that the training program increased the adoption of cultivation practice and then brought the participants of training were better-off.

Table 6. Average score from initial impact assessment.

\begin{tabular}{|cl|c|c|}
\hline & \multicolumn{2}{|c|}{ Average score out of 5 } \\
\hline \multicolumn{2}{|c|}{ Topic on: } & Knowledge & Intention \\
\hline 1. & Horticulture & 3.5 & 3.4 \\
\hline 2. & Estate crops & 3.5 & 3.2 \\
\hline 3. & Livestock & 3.3 & 3.1 \\
\hline
\end{tabular}

\section{Conclusion and recommendation}

Thus, according to the experience in conducting virtual and on-site Bimtek, the successful technical training would be strongly influenced by four key factors, including: (i) technology readiness to be applied; (ii) delivery agents; (iii) delivery methods; and (iv) targeted farmers as end users of technology. Before Covid-19 pandemic, the most technical trainings were conducted through on-site or face-to-face meetings. During the pandemic, the on-site training seems to bring a high risk of virus contamination among attendees. Hence, the virtual training is an alternative method of technology dissemination during this pandemic.

Based on the result of analysis in this paper, the virtual Bimtek could bring the higher percentage of knowledge change compared to that in on-site Bimtek. The advantages of virtual Bimtek outweighed its disadvantages, particularly during the Covid-19 pandemic. However, in general, both Bimtek could improve farmers' knowledge, from which the intention to change on the farming practice could be persuaded.

\section{References}

1. Statistic of Indonesia (2020)

2. National Development Planning Agency, Indonesia and The World Economic Development Report (2020)

3. Ministry of Agriculture, Indonesia. 2021. https://www.pertanian.go.id/

4. Indonesia Agency for Agricultural Research and Development (2014)

5. N. S. Chesterman, J. Entwistle, M. C. Chambers, H. C. Liu, A. Agrawal, D. G. Brown, Land Use Policy, 86 https://doi.org/10.1016/j.landusepol.2019.104051 (2019)

6. FAO, Extension and advisory services: at the frontline of the response to COVID-19 to ensure food security, Rome, https://doi.org/10.4060/ca8710en (2020)

7. Correia and Santos, Game-based learning: The use of Kahoot in teacher education in International Symposium on Computers in Education (SIIE) 2017, Lisbon, Portugal (2017) 
8. S.A. Licorish, H.E. Owen, B. Daniel, J.L. George, Students' perception of Kahoot!'s influence on teaching and learning, Research and Practice in Technology Enhanced Learning, 13 (9) (2018)

9. J. A. Colquitt, J. A. LePine, R. A. Noe, R. A. Journal of Applied Psychology, 85 (5): 678-707. https://doi.org/10.1037/0021-9010.85.5.678 (2000)

10. B. Ozkeser. Procedia 3rd World Conference on Technology, Innovation and Entrepreneurship (WOCTINE), Computer Science 158: 802-810 (2019)

11. A. Widyastuti, U. P. Astuyi, R. D . Wahyuningrum, The role of extension methods (Technical training) towards knowledge increase of extension workers in Yogyakarta Province in Proceeding National Scientific Concert, 2 July 2019, Yogyakarta, Indonesia (2019)

12. S. S. Tan, R. Indrasti. JPPTP, 21(3) : 245-257 (2018)

13. G.O. Manurung, R. Mawardi, M. M. Andarias, Improvement of participant's knowledge in training about planting season using classroom and practice in Lampung Province in Proceeding of National Seminar on Agro Innovation of Site-Specific for Food Security in Economy Community of ASEAN (2016)

14. D. Asfaw, M. Neka. International Soil and Water Conservation Research. 5 : 273-279 (2017)

15. A. A. T. Altalb, T. Filipek, P. Skowron. Asian Journal of Agriculture and Food Sciences 03 (05): 500-507 (2015)

16. F. Lestari, T.C. Mardiyanto. Jurnal Fakultas Pertanian UNS 1 (1): 464-473 (2017)

17. A. Haslinda, M.Y. Mahyuddin. American J. of Scientific Research, $6: 39$ - 51 (2009)

18. Y. Kijima, Y. Ito, K. Otsuka, World Development 40 (8): 1610-1618 http://dx.doi.org/10.1016/j.worlddev.2012.04.008 (2012) 